\title{
Hormone production by the intact human corpus luteum in vitro
}

\author{
J. S. G. Biggs* and T. G. Baker \\ Hormone Laboratory, Department of Obstetrics \& Gynaecology, \\ University of Edinburgh, Edinburgh EH3 9EW, U.K.
}

\begin{abstract}
Summary. Human CL removed during the menstrual cycle were cultured for up to 5 days. Production of progesterone, measured by radioimmunoassay of the culture fluid, continued throughout each experiment. Addition of hCG to the culture medium stimulated progesterone production in a biphasic manner.
\end{abstract}

\section{Introduction}

Information on steroid hormone production by the corpus luteum (CL) has mostly been obtained indirectly by the measurement of urinary or blood levels of hormones which characterize the luteal phase of the ovarian cycle. Studies have also been carried out in which slices (LeMaire, Rice \& Savard, 1968; LeMaire et al., 1971; Marsh, Savard \& LeMaire, 1976) or homogenates (Ryan, 1963) of the CL have been incubated for short periods and hormone production measured by assay of the culture fluid. In all in-vitro studies there is loss of the normal blood supply to the tissues, and slicing or homogenization may add cell damage and disruption of normal cellular interrelationships to the problems faced in culture experiments. A method by which tissue disruption may be minimized is culture of the whole gland and this is possible for a discrete tissue such as the corpus luteum. The present paper describes organ culture studies of the intact human CL for up to 5 days.

\section{Materials and Methods}

\section{Tissue collection and culture}

Ovarian tissue was obtained from women undergoing oophorectomy for reasons unrelated to the present study (e.g. non-invasive cervical cancer). Menstrual cycles were regular in each case and the dates provided by the patient were verified by histological examination of endometrial biopsies obtained at the time of surgery.

The ovarian biopsies were placed in Eagle's medium (see below) at $4^{\circ} \mathrm{C}$ and were dissected within $2 \mathrm{~h}$. Each $\mathrm{CL}$ was carefully trimmed of other ovarian tissues and photographed against a graduated background to obtain a record of its appearance and size. It was then placed on lens tissue supported on a stainless steel platform in a $5-\mathrm{cm}$ plastic Petri dish. More lens tissue was draped over the $\mathrm{CL}$ so that the edges touched the culture fluid on each side of the stainless steel grid. In this way the $\mathrm{CL}$ received nutrients (and seemingly released hormones) by capillary action in the lens tissue, but was not immersed in the fluid (Baker, Hunter \& Neal, 1975).

The culture fluid comprised Eagle's minimum essential medium with Hepes buffer and Earle's salts, to which were added newborn calf serum $(20 \%)$, Kanamycin $(40 \mu \mathrm{g} / \mathrm{ml})$, and Amphotericin B $\left(2 \mu \mathrm{g} / \mathrm{ml}\right.$ ) (all from Flow Laboratories, Irvine, U.K.). The tissue was cultured at $37^{\circ} \mathrm{C}$ in an atmosphere of $5 \% \mathrm{CO}_{2}, 57 \% \mathrm{O}_{2}$ and $38 \% \mathrm{~N}_{2}$ at $0.703 \mathrm{~kg} / \mathrm{cm}^{2}$ above atmospheric pressure in modified 'Kilner' glass preserving jars (Baker \& Neal, 1969).

* Present address: Department of Obstetrics \& Gynaecology, University of Queensland, Royal Brisbane Hospital, Queensland 4029, Australia. 
After first ensuring thorough mixing in the culture dish, the culture medium was removed for hormone assay. Sometimes the fluid was completely replaced with fresh medium as above, with or without gonadotrophins: the CL was washed by playing a jet of $4 \mathrm{ml}$ medium over the gland before adding the replacement medium. At other times $0.1 \mathrm{ml}$ of the fluid was removed every hour for assay and replaced by $0 \cdot 1 \mathrm{ml}$ fresh medium. The used medium was stored at $-18^{\circ} \mathrm{C}$ until assayed.

Cultures were treated with hCG (Pregnyl: Organon) at a dose of 5 or $7 \mathrm{i} . \mathrm{u} . / \mathrm{ml}$ culture medium, or with human pituitary gonadotrophin (hPG: Commonwealth Serum Laboratories, Melbourne) at a dose of 0.4 i.u. $/ \mathrm{ml}$. The potency of the hPG was determined against the 2nd IRP hMG and the ratio of FSH: $\mathrm{LH}$ in the material was $1 \cdot 6: 1 \cdot 0$ (B. M. Hobson, personal communication).

\section{Steroid assays}

Oestradiol in the culture medium was measured using a radioimmunoassay developed by Fraser, Leask, Drife, Bacon \& Michie (1976). The antiserum was raised in sheep to oestradiol-17 $\beta-17$ hemisuccinate-bovine serum albumin (provided by Dr G. Abraham), and cross-reacted with oestrone $(35 \%)$ and oestriol $(2 \cdot 3 \%)$. An internal standard of tritiated oestradiol was added to the samples to measure extraction and column recovery (see Fraser et al., 1976). Mean recoveries ( \pm s.d.) in two assay runs were $76 \cdot 5 \pm 7 \cdot 5 \%(n=78)$ and $74.3 \pm 6.7 \%(n=34)$. With $1 \mathrm{ml}$ culture medium a lower limit of sensitivity of $150 \mathrm{pg} / \mathrm{ml}$ was obtained. The coefficient of variation was $10 \cdot 4 \%(n=10)$ between assays and $7.9 \%(n=25)$ within assays. Unused culture medium (i.e. control blank) always gave readings below the lowest point on the standard curve. The addition of oestradiol-17 $\beta$ to the culture medium at concentrations of 3.0 and $6.0 \mathrm{ng} / \mathrm{ml}$ gave assay means $( \pm$ s.d.) of $3.08 \pm 0.37 \mathrm{ng} / \mathrm{ml}$ $(n=12)$ and $6 \cdot 27 \pm 0.66 \mathrm{ng} / \mathrm{ml}(n=12)$.

Progesterone was measured by the radioimmunoassay method of Neal, Baker, McNatty \& Scaramuzzi (1975), which was a modification of that of Scaramuzzi, Corker, Young \& Baird (1975), for measurement in culture medium rather than serum. The antiserum was raised in rabbits to progesterone-11 $\alpha$-bovine serum albumin (see Scaramuzzi et al., 1975); significant cross-reactions occurred with $11 \alpha$ - and $11 \beta$-hydroxyprogesterone (121 and $77 \%$ respectively; progesterone $100 \%)$, and with 11-keto-progesterone $(82 \%)$. The specificity of the antibody has been discussed by Dighe $\&$ Hunter (1974). The coefficient of variation between assays was $14.8 \%(n=11)$, and within assays was $5 \%(n=64)$. Progesterone was not detectable in blank (unused) culture medium and the lowest detectable amount was $200 \mathrm{pg}$ progesterone $/ \mathrm{ml}$. The addition of 780,3120 or $6250 \mathrm{pg}$ progesterone $/ \mathrm{ml}$ to fresh culture medium gave assay values (mean \pm s.d., $n=6$ ) of $785 \pm 37 \cdot 8,3216 \cdot 7 \pm 222.9$ and $6566 \cdot 7 \pm 463 \cdot 2 \mathrm{pg} / \mathrm{ml}$ respectively.

\section{Histology}

After culture the CL were fixed in Bouin's fluid and processed for histology. Serial sections cut at $5 \mu \mathrm{m}$ were stained with haematoxylin and eosin and their appearance in the light microscope was compared with that of other CL from the same stage of the menstrual cycle, processed and stained in the same way but fixed immediately after surgical recovery.

\section{Results}

\section{Histology}

Apart from a slight reduction in the affinity of the cells for haematoxylin and eosin, the histology of the cultured CL was similar to that of non-cultured controls. However, the luteal cells in cultured CL appeared to have shrunk slightly causing an increase in the extent of intercellular spaces, but there were no signs of pyknosis in any region of the tissue (Plate 1).

\section{Production of steroid hormones}

As shown in Table 1, progesterone was produced throughout the period of culture (up to $126 \mathrm{~h}$ ). It was relatively unaffected by the duration of culture. The addition of hPG to the medium of CL No. 29 gave an increase (to $176 \%$ ) in production of progesterone while oestradiol levels declined

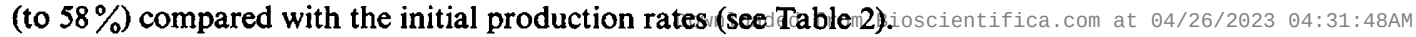


PLATI: I
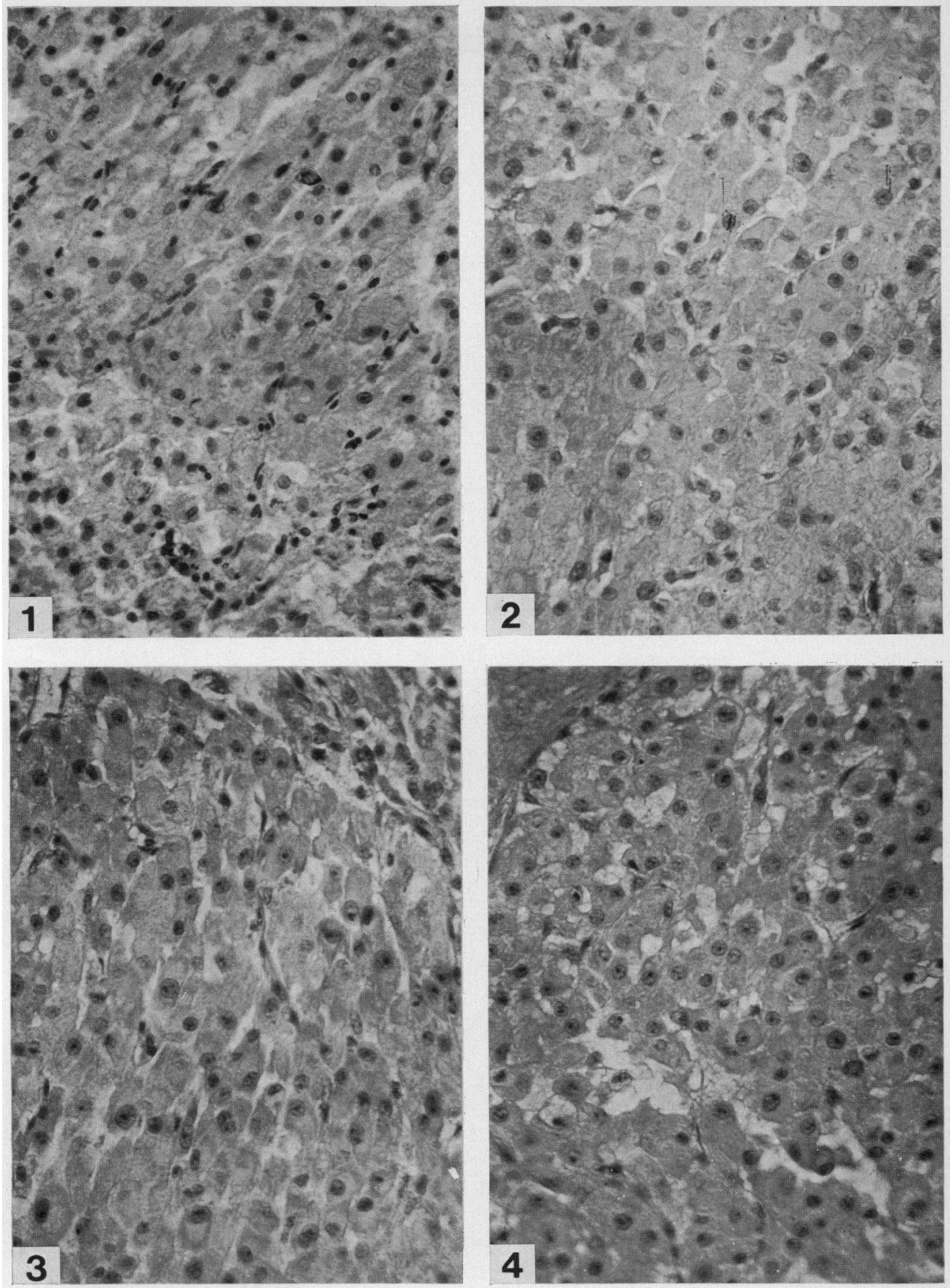

Human corpora lutea. stained with haematoxylin and eosin, $\times 100$.

Fig. 1. Outer region of a CL cultured for $126 \mathrm{~h}$. The luteal cells are smaller than those in non-cultured controls (Fig. 3).

Fig. 2. Central region of the same CL, shown in Fig. 1. The cells have been maintained in culture although some cytological changes can be seen.

Fig. 3. Outer region of a control (non-cultured) corpus luteum tixed immediately after surgery. Compare with Fig. 1.

Fig. 4. Central region of the same (I. as shown in Fig. 3. Compare with Fig. 2 
Table 1. Hormone production by whole human corpora lutea maintained throughout the entire period of culture, including the time of stimulation with gonadotrophins

\begin{tabular}{|c|c|c|c|c|c|c|c|c|}
\hline \multirow[b]{2}{*}{ CL No. } & \multirow{2}{*}{$\begin{array}{l}\text { Day of } \\
\text { cyclet }\end{array}$} & \multirow{2}{*}{$\begin{array}{l}\text { Diam. } \\
(\mathrm{mm})\end{array}$} & \multirow{2}{*}{$\begin{array}{c}\text { Calculated } \\
\text { wt } \ddagger(g)\end{array}$} & \multirow{2}{*}{$\begin{array}{l}\text { Total time } \\
\text { cultured (h) }\end{array}$} & \multicolumn{2}{|c|}{ Total production $(\mu \mathrm{g})$} & \multicolumn{2}{|c|}{ Production rate $\left(\mu \mathrm{g} / \mathrm{g} \cdot 24 \mathrm{~h}^{-1}\right)$} \\
\hline & & & & & Progesterone & Oestradiol & Progesterone & Oestradiol \\
\hline $\mathrm{H} 26$ & $16-18$ & 14 & $1 \cdot 4$ & 29 & $24 \cdot 5^{*}$ & $2 \cdot 3$ & $16 \cdot 8^{*}$ & 1.4 \\
\hline H29 & $22-23$ & 13 & $1 \cdot 2$ & 76 & $32 \cdot 4$ & 0.8 & $8 \cdot 5$ & 0.2 \\
\hline H33 & 20 & 10 & 0.5 & 46 & $14 \cdot 7$ & $4 \cdot 2$ & $15 \cdot 3$ & 4.4 \\
\hline H35a & 25 & 10 & 0.5 & 126 & $27 \cdot 2$ & 7.4 & 10.4 & $2 \cdot 8$ \\
\hline $\mathrm{H} 35 \mathrm{c}$ & 25 & 10 & 0.5 & 126 & $44 \cdot 8$ & 10.9 & $17 \cdot 1$ & $4 \cdot 2$ \\
\hline
\end{tabular}

* Measured over $25 \mathrm{~h}$.

$\dagger$ Day 1 = first day of menstrual bleeding.

¥ Calculated from mean diameter, assuming density of 1 .

Table 2. Mean hormone production (ng/h) by whole corpora Iutea treated with gondadotrophins

\begin{tabular}{|c|c|c|c|c|c|c|c|}
\hline \multirow[b]{2}{*}{ CL No. } & \multicolumn{3}{|c|}{ Initial hormone production } & \multirow{2}{*}{$\begin{array}{l}\text { Treatment } \\
\text { (i.u. } / \mathrm{ml} \text { ) }\end{array}$} & \multicolumn{3}{|c|}{ Subsequent hormone production } \\
\hline & Time (h) & Progesterone & Oestradiol & & Time (h) & Progesterone & Oestradiol \\
\hline $\mathrm{H} 29$ & 53 & 347 & 12 & hPG & 23 & 609 & 7 \\
\hline H33 & 21 & 199 & 90 & $\begin{array}{l}\text { hCG (7) } \\
\text { Wash }\end{array}$ & $\begin{array}{r}7 \\
18\end{array}$ & $\begin{array}{l}538 \\
222\end{array}$ & $\begin{array}{l}14 \\
93\end{array}$ \\
\hline $\mathrm{H} 35 \mathrm{a}$ & 23 & 105 & 79 & $\begin{array}{l}\text { hCG (5) } \\
\text { Wash } \\
\text { Wash } \\
\text { hCG (5) }\end{array}$ & $\begin{array}{r}7 \\
24 \\
65 \\
7\end{array}$ & $\begin{array}{l}276 \\
278 \\
138 \\
488\end{array}$ & $\begin{array}{r}205 \\
108 \\
10 \\
9\end{array}$ \\
\hline H35c & 23 & 112 & 78 & $\begin{array}{l}\text { hCG (5) } \\
\text { Wash } \\
\text { Wash } \\
\text { hCG (5) }\end{array}$ & $\begin{array}{r}7 \\
24 \\
65 \\
7\end{array}$ & $\begin{array}{r}869 \\
374 \\
196 \\
1058\end{array}$ & $\begin{array}{r}823 \\
85 \\
5 \\
11\end{array}$ \\
\hline
\end{tabular}

The addition of hCG to the culture fiuid also enhanced the production of progesterone when first added and after $96 \mathrm{~h}$ (Table 2). The changes in oestradiol production were variable. For example, the oestradiol output of CL No. 33 fell to $16 \%$ of the pretreatment value whereas that of CL Nos $35 \mathrm{a}$ and $35 \mathrm{c}$ increased to 259 and $1055 \%$ of the initial rates.

A close examination of the results for CL Nos 35a and 35c showed that after hCG additions progesterone was produced in a biphasic fashion: it increased by a mean factor of 5.7 (1.8-11.0, $n=4$ ) during the first $1-2 \mathrm{~h}$ of treatment, decreased during the next hour, and then increased again between 3 and $7 \mathrm{~h}$ after addition of hCG by a mean factor of $9 \cdot 4(4 \cdot 0-22 \cdot 0, n=4)$. The pattern of increased production of oestradiol also appeared to be biphasic. Output rose in the first hour after hCG addition by a factor of 3, and at 5-7 h by a factor of 8 in CL No. 35a and of 33 in No. 35c.

\section{Discussion}

There have been few quantitative studies of hormone production by the human CL in vitro. LeMaire et al. (1968), studying CL slices in culture, showed a mean production of progesterone in the luteal phase of the menstrual cycle of $55 \mu \mathrm{g} / \mathrm{g}$ tissue over $3 \mathrm{~h}$ for 9 glands when corrections were made for initial hormone concentrations. Information is also available from studies in which steroids were extracted from corpora lutea removed at surgery; e.gedZander, Forbes, . Von Münstermann $4: 31: 48 \mathrm{AM}$ 
\& Neher (1958) reported a mean progesterone concentration of $14.65 \mu \mathrm{g} / \mathrm{g}$ tissue in 29 human CL and Stutt et al. (1976) found a mean progesterone and oestradiol concentration of 10.8 and $0.11 \mu \mathrm{g} / \mathrm{g}$ respectively in 24 recent human CL.

The results of the present study show, firstly, that the whole human CL can produce hormones throughout a prolonged culture period. During periods of up to 5 days the mean daily production of progesterone was similar to the mean static concentrations reported by Zander et al. (1958) and Shutt et al. (1976) and the mean daily oestradiol production exceeded the static concentrations found by Shutt et al. (1976) in 4 out of 5 cases. The rates of progesterone production were within a fairly narrow range $(8 \cdot 5-17 \cdot 1 \mu \mathrm{g} / \mathrm{g}$ per day; mean value $13.6 \pm 3.9$ (s.d.) $\mu \mathrm{g} / \mathrm{g}$ per day) but were much smaller than those reported (see above) by LeMaire et al. (1968). The difference in progesterone production may be due to poorer diffusion of metabolites into (and of steroids out of) the corpus luteum in our studies. It is also possible that the short-term incubations of LeMaire et al. (1968) are measuring different aspects of in-vitro hormone production.

Additions of gonadotrophins to the culture medium resulted in stimulation of progesterone production by all 5 CL studied. Similar effects were described by LeMaire et al. (1968) for the culture of CL slices. The variation in the oestradiol response may be related to the stage of the menstrual cycle at which the CL were removed and more studies of this possibility are needed. Alternatively, the shorter-lived production of oestrogen may be due to its origin from more vulnerable cells in the cultured $\mathrm{CL}$, or to steps in the oestrogenic pathways being more susceptible to the in-vitro conditions employed.

In the present study, the CL responded to hCG by a biphasic secretion of progesterone with a peak in the first hour and at 3-7 h. Watson \& Wrigglesworth (1975) have described a biphasic response to $\mathrm{LH}$ in studies with slices of pig $\mathrm{CL}$ and suggested that the initial response was due to increased release of preformed hormone while the second peak was the result of accelerated synthesis of new hormone. Savard (1973) indicates that the initial steroidogenic response of luteal cells to LH in vitro occurs within $10-20 \mathrm{~min}$.

The ability of the intact human $\mathrm{CL}$ to respond to stimulation after $119 \mathrm{~h}$ in culture, and the normal histological appearance of the tissues after culture, suggests that at least some of the functions of the gland have been maintained and the culture system may be of further value in studies on the corpus luteum. However, parallel studies of porcine corpora lutea with the same culture system have failed to reveal any stimulatory or inhibitory effects with added LH, hCG, prostaglandin E-2 or prostaglandin F-2 $\alpha$ (K. Kucheria, M. G. Hunter \& T. G. Baker, unpublished results).

This work was assisted by grants to T.G.B. from the Population Council and the Ford Foundation. The hPG used in the study was provided by the Australian Human Pituitary Advisory Committee. The technical assistance of Mrs Gail Graham, Miss Rose Leask, Mrs Anne Rae and Mr H. P. Boyle is gratefully acknowledged.

\section{References}

Baker, T.G. \& NeAL, P. (1969) The effects of Xirradiation on mammalian oocytes in organ culture. Biophysik 6, 39-45.

Baker, T.G., Hunter, R.H.F. \& Neal, P. (1975) Studies on the maintenance of porcine Graafian follicles in organ culture. Experientia 31, 133-135.

Dighe, K.K. \& Hunter, W.M. (1974) A solid-phase radioimmunoassay for plasma progesterone. Biochem. J. 143, 219-231.

Fraser, I.S., LeAsK, R., Drife, J., Bacon, L. \& Michie, E. (1976) Plasma estrogen response to dehydroepiandrosterone sulphate injection in normal and complicated late pregnancy. Obstet. Gynec. 47, 152-158.
LeMaire, W.J., Rice, B.F. \& Savard, K. (1968) Steroid hormone formation in the human ovary. V. Synthesis of progesterone in vitro in corpora lutea during the reproductive cycle. J. clin. Endocr. Metab. 28, 1249-1256.

LeMaire, W.J., Conly, P.W., Moffett, A., Spellacy, W.N., Cleveland, W.W. \& Savard, K. (1971) Function of the human corpus luteum during the puerperium: its maintenance by exogenous human chorionic gonadotropin. Am. J. Obstet. Gynec. 110, 612-618.

Marsh, J.M., SAVARD, K., \& LeMaire, W.J. (1976) Steroidogenic capacities of the different compartDown lments of the human ovary. In The Endocfine Function 
of the Human Ovary, pp. 37-45. Eds V. H. T. James, M. Serio \& G. Giusti. Academic Press, London.

Neal, P., Baker, T.G., McNatty, K.P. \& ScaraMUZZ,, R.J. (1975) Influence of prostaglandins and human chorionic gonadotrophin on progesterone concentration and oocyte maturation in mouse ovarian follicles maintained in organ culture. $J$. Endocr. 65, 19-25.

RYaN, K.J. (1963) The conversion of pregnenolone$7-{ }^{3} \mathrm{H}$ and progesterone-4- ${ }^{14} \mathrm{C}$ to oestradiol by a corpus luteum of pregnancy. Acta endocr., Copenh. 44, 81-89.

Savard, K. (1973) The biochemistry of the corpus luteum. Biol. Reprod. 8, 183-211.

SCaramuzzi, R.J., Corker, C.S., Young, G. \& Baird, D.T. (1975) Production of antisera to steroid hormones in sheep. In Steroid Immunoassay, pp.
111-122. Eds E. H. D. Cameron, S. G. Hillier \& K. Griffiths. Alpha Omega Publishing Co., Cardiff.

Shutt, D.A., Clarke, A.H., Fraser, I.S., Goh, P., McMahon, G.R., Saunders, D.M. \& Shearman, R.P. (1976) Changes in concentration of prostaglandin $F$ and steroids in human corpora lutea in relation to growth of the corpus luteum and luteolysis. J. Endocr. 71, 453-454.

Watson, J. \& Wrigglesworth, P.M. (1975) Progesterone synthesis by pig corpus luteum tissue during superfusion. Biochem. J. 150, 301-304.

Zander, J., Forbes, T.R., Von Münstermann, A.M. \& NEHER, R. (1958) $\Delta^{4}-3-$ Ketopregnene-20 $\alpha$-ol and $\Delta^{4}$-3-ketopregnene-20 $\beta$-ol, two naturally occurring metabolites of progesterone. Isolation, identification, biological activity and concentration in human tissues. J. clin. Endocr. Metab. 18, 337-353.

Received 24 October 1977 